O. WIESŁAW KIWIOR OCD

Wydział Prawa Kanonicznego

Uniwersytetu Kardynała Stefana Wyszyńskiego w Warszawie

ORCID 0000-0001-7378-1256

\title{
ORZECZENIE NIEWAŻNOŚCI ŚWIĘCEŃ W PROCESIE ADMINISTRACYJNYM
}

Treść: Wstęp. - 1. Kompetencja Urzędu Administracyjnego przy Rocie Rzymskiej. - 2. Prawo do zaskarżenia ważności święceń. - 3. Pismo skargowe. - 4. Postępowanie. - 4.1. Postępowanie przed ordynariuszem. 4.1.1. Mianowanie urzędników. - 4.1.2. Obowiązki i prawa instruktora sprawy i obrońcy święceń. - 4.1.2.1. Obowiązki i prawa instruktora sprawy. 4.1.2.2. Obowiązki i prawa obrońcy święceń. - 4.1.3. Odpowiedzialność ordynariusza. - 4.1.4. Przebieg instrukcji sprawy. - 4.1.4.1. Wezwanie petenta i świadków. - 4.1.4.2. Oświadczenia petenta i zeznania świadków. - 4.1.4.3. Uprawnienia petenta wobec świadków. - 4.1.4.4. Dowód $\mathrm{z}$ dokumentów. - 4.1.4.5. Opinie biegłych. - 4.1.4.6. Zakończenie instrukcji sprawy. - 4.1.5. Opinie obrońcy święceń, instruktora sprawy i ordynariusza. - 4.1.6. Język stosowany w redagowaniu akt. - 4.1.7. Przygotowanie akt postępowania do przesłania do Stolicy Apostolskiej. - 4.1.8. Przesłanie akt do Stolicy Apostolskiej. - 4.2. Postępowanie w Urzędzie Administracyjnym przy Rocie Rzymskiej. - 4.2.1. Powołanie urzędników do konkretnej sprawy. - 4.2.2. Nawiązanie kontaktu z petentem i ewentualne uzupełnienie instrukcji sprawy. - 4.2.3. Votum obrońcy święceń. - 4.2.4. Studium akt sprawy i podjęcie decyzji rozstrzygającej. - 4.2.5. Zaskarżenie decyzji końcowej. - Zakończenie 


\section{Wstęp}

Jednym ze sposobów utraty stanu duchownego, nabytego przez przyjęcie święceń diakonatu ${ }^{1}$, jest stwierdzenie nieważności przyjętych święceń ${ }^{2}$. Kodeks Prawa Kanonicznego z 1983 roku postanawia, że może się to dokonać na drodze sądowej, prowadzącej do wydania wyroku, albo na drodze administracyjnej, kończącej się wydaniem dekretu administracyjnego ${ }^{3}$. Postępowanie sądowe ustawodawca kościelny określił ogólnie w kan. 1708-1712, natomiast postępowanie administracyjne - po wejściu w życie aktualnego Kodeksu dla Kościoła Katolickiego obrządku łacińskiego - było nadal regulowane przepisami z czasów Kodeksu Prawa Kanonicznego z 1917 roku, a konkretnie Regulae servandae z 9 czerwca 1931 roku, wydanymi przez Kongregację Dyscypliny Sakramentów ${ }^{4}$. Nowe przepisy, regulujące procedurę administracyjną $\mathrm{w}$ rozpoznawaniu i orzekaniu nieważności święceń, zostały wydane 16 października 2001 roku przez Kongregację Kultu Bożego i Dyscypliny Sakramentów ${ }^{5}$, które od 1 października 2011 roku

\footnotetext{
${ }^{1}$ „Przyjmujący diakonat staje się duchownym (...)” (Codex Iuris Canonici auctoritate IoAnnis Pauli PP. II promulgatus. Kodeks Prawa Kanonicznego. Przekład polski zatwierdzony przez Konferencję Episkopatu [KPK 1983], Pallottinum, Poznań 1984, kan. $266 \$ 1)$.

${ }^{2}$ Por. tamże, kan. $290,1^{\circ}$.

3 „Święcenia raz ważnie przyjęte nigdy nie tracą ważności. Jednakże duchowny traci stan duchowny: $1^{\circ}$ przez wyrok sądowy lub dekret administracyjny, stwierdzający nieważność święceń" (tamże).

${ }^{4}$ Sacra Congregatio De Disciplina Sacramentorum, Regulae servandae in processibus super nullitate sacrae ordinationis vel onerum sacris ordinibus inherentium, [RS 1931], 9 iunii 1931, AAS 23 (1931) 457-492. O takiej praktyce piszą: A. González Martín, La nulidad en la sagrada ordenación, Ius Canonicum 23 (1983) 594; J. Punderson, De causis ad sacrae ordinationis nullitatem declarandam, w: Comentario exegético al Código de Derecho Canónico, VI/2, EUNSA, Pamplona 1997, 2016; L. NAVArro, Le nuove "regulae servandae" per le cause di nullità della sacra ordinazione, Ius Ecclesiae 15/1 (2003) 314 i 326; P. AMENTA, La nuova normativa per lo svolgimento delle cause di dichiarazione di nullità dell'ordinazione: commento e primi rilievi, Folia Canonica 5 (2002) 163, 172-173.

${ }^{5}$ Por. Congregatio De Cultu Divino Et Disciplina Sacramentorum, Regulae servandae ad proceduram administrativam nullitatis ordinationis inchoandam et celebrandam noviter confectae, [RS 2001], w: Enchiridion Vaticanum [EV],
} 
są stosowane zgodnie ze zmianami wprowadzonymi przez papieża Benedykta XVI w motu proprio Quaerit semper, z 30 sierpnia 2011 roku $^{6}$. Ich postanowienia, z uwzględnieniem wspomnianych zmian, są przedmiotem niniejszego studium.

\section{Kompetencja Urzędu Administracyjnego przy Rocie Rzymskiej}

Rozpatrywanie spraw dotyczących nieważności święceń należy do kompetencji Stolicy Apostolskiej. Do 30 września 2011 roku, na podstawie kan. $1709 \$ 2$ i związanego z nim art. 68 konstytucji apostolskiej Pastor Bonus, należała ona do Kongregacji Kultu Bożego i Dyscypliny Sakramentów ${ }^{7}$, natomiast od 1 października 2011 roku należy ona do kompetencji Urzędu Administracyjnego przy Rocie Rzymskiej, utworzonego przez papieża Benedykta XVI na mocy wspomnianego motu proprio Quaerit semper ${ }^{9}$, w którym Biskup Rzymu uchylił artt. 67 i 68 konstytucji apostolskiej Pastor Bonus ${ }^{10}$, a ich treści, odpowiednio zmodyfikowane, znalazły się w rozszerzonym art. 126 jako $\$ \$ 2-3$ tejże konstytucji, mówiącym o Trybunale Roty Rzymskiej ${ }^{11}$. W ten sposób kompetencja dotycząca rozpatrywania spraw odnoszących się do dyspensy od matrimonium ratum et

XX,Bologna 2004, 1276-1297. Wspomniane Regulae servandae nie są ustawą, lecz instrukcją: “(...) praesentes Regulae Servandae ad normam can. 34 Codicis Iuris Canonici redactae" (Congregatio De Cultu Divino Et Disciplina SacramenTORum, Decretum Ad satius tutiusque, 16.10.2001, w: EV, XX, 1278.

${ }^{6}$ Benedictus XVI, Litterae apostolicae motu proprio Quaerit semper [QS], 30.08.2011, w: EV, XXVII, Bologna 2013, 378-383.

${ }^{7}$ Por. PB art. 68.

${ }^{8}$ Takiego określenia przedmiotowego urzędu używają J. Llobell i G. Erlebach (audytor rotalny): J. Llobell, Il m.p. "Quaerit semper" sulla dispensa dal matrimonio non consumato e le cause di nullità della sacra ordinazione, Stato, Chiese e pluralismo. Rivista telematica 24 (2012) 3, 8-12, 46-47, 51-52; G. ERLEBACH, Nuove competenze della Rota Romana in seguito al Motu proprio Quaerit semper, Ius et Iustitia 16 (2012) 200-203.

9 "Apud hoc tribunal officium est constitutum (...)." (QS art. 2).

${ }^{10}$ Por. tamże, art. 1.

${ }^{11}$ Por. tamże, art. 2. 
non consummatum (art. 67) i nieważności święceń (art. 68) została przeniesiona - w ramach modyfikacji kompetencji dykasterii Kurii Rzymskiej - z Kongregacji Kultu Bożego i Dyscypliny Sakramentów do nowo utworzonego Urzędu Administracyjnego przy Rocie Rzymskiej ${ }^{12}$, posiadającego - jak podkreślają autorzy - swoją autonomię ${ }^{13}$, „swoją własną strukturę, z odrębnym personelem”'14. Nowo powołanym Urzędem kieruje dziekan Trybunału Roty Rzymskiej, przy wsparciu urzędników, deputowanych komisarzy i konsultorów ${ }^{15}$.

12 “Art. $126 \$(. .)$.2 . Apud hoc Tribunal Officium est constitutum, cuius est cognoscere de facto inconsummationis matrimonii et de exsistentia iustae causae ad dispensationem concedendam. (...). $\$ 3$. Hoc Officium competens quoque est in causis de nullitate sacrae Ordinationis cognoscendis ad normam iuris communis et proprii, congrua congruis referendo." (tamże).

${ }^{13}$ Por. R. Rodríguez Chacón, “Quaerit semper” ¿Nuevas competencias para el Tribunal de la Rota Romana?, Revista General de Derecho Canónico y Derecho Eclesiástico del Estado 28 (2012) 6-10; J. LlobelL, Il m.p. "Quaerit semper" sulla dispensa dal matrimonio non consumato e le cause di nullità della sacra ordinazione, Stato, Chiese e pluralismo. Rivista telematica 24 (2012) 3-10; G. ErLeBACH, Nuove competenze della Rota Romana in seguito al Motu proprio Quaerit semper, Ius et Iustitia 16 (2012) 199-203. Inni autorzy mówią o pewnej odrębności nowego urzędu: A. Stankiewicz, Un'innovazione storica. [Commento al m.p. "Quaerit semper"], Ius Ecclesiae 24/2 (2012) 460; W. GóraLSKI, Nowe kompetencje Trybunału Roty Rzymskiej, Stowarzyszenie Kanonistów Polskich. Biuletyn nr 2623 (2013) 71.

${ }^{14} \mathrm{G}$. ERlebach, Nuove competenze della Rota Romana in seguito al Motu proprio Quaerit semper, Ius et Iustitia 16 (2012) 202.

${ }^{15}$ Por. QS art. 3. Na temat natury nowego urzędu piszą: C. PeÑa García, Nuevas competencias de la Rota Romana en los procedimientos de disolución del matrimonio rato y no consumado: el Motu proprio "Quaerit semper" de Benedicto XVI, Estudios Ecclesiásticos 86 (2011) 820; A. STANKIEWICZ, Un’innovazione storica. [Commento al m.p. "Quaerit semper"], Ius Ecclesiae 24/2 (2012) 460; R. RodRíguez Chacón, "Quaerit semper" ¿Nuevas competencias para el Tribunal de la Rota Romana?, Revista General de Derecho Canónico y Derecho Eclesiástico del Estado 28 (2012) 6-10; J. LlOBELL, Il m.p. "Quaerit semper" sulla dispensa dal matrimonio non consumato e le cause di nullità della sacra ordinazione, Stato, Chiese e pluralismo. Rivista telematica 24 (2012) 3-10; G. Erlebach, Nuove competenze della Rota Romana in seguito al Motu proprio Quaerit semper, Ius et Iustitia 16 (2012) 199-203; W. GóRALSKI, Nowe kompetencje Trybunału Roty Rzymskiej, Stowarzyszenie Kanonistów Polskich. Biuletyn nr 2623 (2013) 71. 


\section{Prawo do zaskarżenia ważności święceń}

Przepisy dotyczące administracyjnego stwierdzania nieważności święceń poszerzyły zakres podmiotów uprawomocnionych do wniesienia stosownej skargi. Kodeks Prawa Kanonicznego z 1983 roku wskazuje: samego duchownego ${ }^{16}$; ordynariusza, któremu duchowny podlega ${ }^{17}$, czyli biskupa diecezjalnego ${ }^{18} \mathrm{i}$ zrównanego $\mathrm{z}$ nim $\mathrm{w}$ prawie prałata terytorialnego, opata terytorialnego, wikariusza apostolskiego, prefekta apostolskiego, administratora apostolskiego ${ }^{19}$ oraz ordynariusza ordynariatu polowego ${ }^{20}$, a także wyższego przełożonego kleryckiego instytutu zakonnego na prawie papieskim i kleryckiego stowarzyszenia życia apostolskiego na prawie papieskim ${ }^{21}$ oraz ordynariusza prałatury personalnej ${ }^{22}$; ordynariusza miejsca, w którego diecezji duchowny został wyświęcony ${ }^{23}$; ordynariusza miejsca stałego zamieszkania (domicilium), tymczasowego zamieszkania (quasi-domicilium) albo aktualnego pobytu (commoratio) ${ }^{24} \mathrm{w}$ przypadku zakonnika-duchownego, który uzyskał indult odejścia z instytutu zakonnego albo został wydalony, ale nie został inkardynowany do diecezji ${ }^{25}$. Natomiast Regulae servandae z 2001 roku uwzględniają ponadto rzecznika sprawiedliwości diecezji inkardynacji i rzecznika

\footnotetext{
${ }^{16}$ Por. KPK 1983, kan. 1708.

${ }^{17}$ Por. tamże.

${ }^{18}$ Por. tamże, kan. $134 \$ 1$.

${ }^{19}$ Por. tamże, kann. 381 i 368.

${ }^{20}$ Por. IoAnnes Paulus II, Constitutio apostolica Spirituali militum cura, 21.04.1086, art. I \$1, w: EV, X, 242.

${ }^{21}$ Por. KPK 1983, kan. $134 \$ 1$. Wyższy przełożony to osoba, która kieruje całym instytutem lub jego prowincją albo inną zrównaną z nią częścią lub domem niezależnym (por. tamże, kan. 620).

${ }^{22}$ Por. tamże, kan. $295 \$ 1$.

${ }^{23}$ Por. tamże, kan. 1708. Może nim być biskup diecezjalny i zrównany z nim w prawie prałat terytorialny, opat terytorialny, wikariusz apostolski, prefekt apostolski, administrator apostolski (por. tamże, kann. 381 i 368).

${ }^{24}$ Por. tamże, kan. $107 \$ \$ 1-2$.

${ }^{25}$ Por. J. Punderson, De causis ad secrae ordinationis nullitatem declarandam, w: Comentario exegético al Código de Derecho Canónico, VI/2, 2018.
} 
sprawiedliwości diecezji, na terenie której duchowny przebywa (dioecesis commorationis) ${ }^{26}$.

Przed instrukcją z 16 października 2001 roku w kanonistyce dyskutowano nad tym, czy rzecznik sprawiedliwości mógłby wnieść skargę, analogicznie do kan. 1674, 2 , jeśli nieważność święceń jest publiczna. Kanon 1708 wyraźnie ogranicza to prawo do samego duchownego i własnego ordynariusza. Problem ten nie był jednak trudny do rozwiązania, ponieważ rzecznik sprawiedliwości mógł poinformować o sprawie ordynariusza. Gdyby ordynariusz nie mógł albo nie chciał podjąć stosownych działań, wówczas rzecznik sprawiedliwości - jak zauważa J. Punderson - mógłby zgłosić sprawę w kompetentnej Dykasterii Kurii Rzymskiej ${ }^{27}$.

Wszystkie inne osoby - poza wymienionymi w kan. 1708 oraz $\mathrm{w}$ art. $2 \$ 1$ instrukcji Regulae servandae - są niezdolne do zaskarżenia ważności święceń. Jeśli jednak byłyby one pewne co do nieważności święceń lub miałyby poważne wątpliwości, mogą, co więcej, mają obowiązek - ze względu na dobro publiczne - przekazać fakt kompetentnej władzy kościelnej, bezpośrednio lub przez pośrednika.

L. Navarro zauważa, że zazwyczaj ważność swoich święceń zaskarża sam duchowny (diakon lub prezbiter) i dlatego przepisy obowiązującej instrukcji zakładają, że to właśnie duchowny jest autorem pisma skargowego ${ }^{28}$.

Duchowny jest uprawniony do wniesienia stosownej skargi, ponieważ przepisy prawa kanonicznego gwarantują mu prawo do dochodzenia i obrony przysługujących mu w Kościele uprawnień na właściwym forum kościelnym ${ }^{29}$, czyli do wyjaśnienia swojego statusu kanonicznego w Kościele i do ewentualnego zawarcia kanonicznego

${ }^{26}$ Por. RS 2001, art. $2 \$ 1$. Na temat pojęcia ordynariusz własny por. C. TAMmARo, Ordinario propio, w: Dicionario General de Derecho Canónico, V, dir. J. Otaduy A. Viana - J. Sedano, Editorial Aranzadi, Pamplona 2012, 825-827.

${ }^{27}$ Por. J. Punderson, De causis ad secrae ordinationis nullitatem declarandam, w: Comentario exegético al Código de Derecho Canónico, VI/2, 2019.

${ }^{28}$ Por. L. NAvarro, Le nuove regulae servandae per le cause di nullità della sacra ordinazione, Ius Ecclesiae 15/1 (2003) 330.

${ }^{29}$ Por. KPK 1983, kan. $221 \$ 1$. 
związku małżeńskiego. Z kolei pozostałe podmioty, wskazane przez ustawodawcę, są również uprawnione do wniesienia przedmiotowej skargi w ramach troski o dobro publiczne w Kościele i o dobro poszczególnych wiernych, aby duchowny, którego święcenia okazałyby się nieważne, nie powodował szkód poprzez nieważne sprawowanie sakramentów Eucharystii i pokuty.

\section{Pismo skargowe}

Pismo skargowe o stwierdzenie nieważności święceń powinno być sporządzone - w myśl instrukcji Regulae servandae z 2001 roku zgodnie z wymaganiami kanonicznego prawa procesowego, określonymi w kann. 1501-1504 ${ }^{30}$. Kierując je do dziekana Roty Rzymskiej jako kierownika Urzędu Administracyjnego przy tejże Rocie, należy w nim podać dane personalne (imię i nazwisko duchownego, datę urodzenia, datę i miejsce przyjęcia święceń, imię i nazwisko szafarza święceń, inkardynację do diecezji albo do instytutu życia konsekrowanego lub stowarzyszenia życia apostolskiego, aktualny adres zamieszkania), sprawowane urzędy, uzasadnienie prawne ${ }^{31}$ i faktyczne,

${ }^{30}$ Por. RS 2001, art. $2 \S 2$.

${ }^{31} \mathrm{Na}$ temat prawa materialnego, dotyczącego nieważności święceń, piszą - w zróżnicowanym zakresie - m.in.: A. González Martín, La nulidad en la sagrada ordenación, Ius Canonicum 23 (1983) 579-589; V. Ferrara, Diritto sostantivo per la dichiarazione di nullità della S. Ordinazione: nozione canonica di validità ed invalidità della S. Ordinazione come sacramento e come atto giuridico, w: Sacramenti, Liturgia, Cause dei Santi. Studi in onore del Cardinale Giuseppe Casoria, a cura di A. Moroni - C. Pinto - M. Bartolucci, Editoriale Comunicazioni Sociali, Napoli, 1992, 168-228; V. MoscA, Le procedure per la perdita dello stato clericale, w: I giudizi nella Chiesa. Processi e procedure speciali, a cura del Gruppo Italiano Docenti Di Diritto Canonico, Edizioni Glossa Srl, Milano 1999, 321-322; A. Perlasca, Materia e forma, tempo e luogo dell'ordinazione presbiterale, Quaderni di diritto ecclesiale 12 (1999) 254-278; L. NAVArRo, Le nuove "regulae servandae" per le cause di nullità della sacra ordinazione, Ius Ecclesiae 15/1 (2003) 325-326; J.S.J. PRIsco, Nuevas normas sobre la nulidad de la ordenación sacerdotal. Texto y comentario, Revista Española de Derecho Canónico 60 (2003) 128-138; M. Pastuszko, Sakrament święceń (kanony 1008-1054), Jedność, Kielce 2008, 47-60, 94-109, 205-235, 239-253; A. Miziński, Proces o stwierdzenie nieważności święceń w aktualnych przepisach Kościoła łacińskiego, 
pełną i dokładną relację wydarzeń związanych z nieważnością święceń oraz inne okoliczności dotyczące sprawy, miejscowość i dokładną datę (dzień, miesiąc, rok) złożenia skargi oraz umieścić podpis ${ }^{32}$.

Do prośby duchownego kompetentny ordynariusz powinien dołączyć swoje informacje, o ile takie istnieją, dotyczące zwłaszcza przyczyn nieważności przedmiotowych święceń. Wspomniane informacje winny być zebrane $\mathrm{w}$ dochodzeniu pozasądowym dotyczącym faktów wskazanych w prośbie przez wnoszącego skargę ${ }^{33}$. W tym celu należy skierować odpowiednie pytania do duchownego i, jeśli okaże się to konieczne, także do świadków. W przypadku wniesienia pisma skargowego przez ordynariusza lub rzecznika sprawiedliwości

Roczniki Nauk Prawnych 22/4 (2012) 169-173; J.S.J. Prisco, Proceso de nulidad de la sagrada ordenación, Revista Española de Derecho Canónico 70 (20013) 605-613; M. SтокŁosA, Utrata stanu duchownego w aktualnym prawodawstwie Kościoła łacińskiego, Wydawnictwo Uniwersytetu Kardynała Stefana Wyszyńskiego, Warszawa 2015, 16-19; G. DegIorgi, Le condizioni soggettive per la valida ordinazione, I-II, Revista Universitas Canonica 32 (2015) 103-132, 133-188; G. LeszczyŃsKi, Utrata stanu duchownego $w$ świetle KPK $z 1983$ r., Łódzkie Studia Teologiczne 25/2 (2016) 106-108; T. JакUвіAк, Problem ważności przyjęcia sakramentu święceń w prawie Kościoła katolickiego, Płocki Instytut Wydawniczy, Płock 2018, 23-338. Problematyka przyczyn nieważności święceń była przedmiotem prac magisterskich: R. RoJAs Marroquín, La nulidad de ordenación sacerdotal. Principios jurídico-canónicos, Praca licencjacka i magisterska, Facultad de Derecho Canónico de Pontificia Universidad Javeriana, Bogotá 2016, 57-93; A. Matula, Orzeczenie nieważności święceń w świetle aktualnych przepisów prawa kanonicznego, Praca magisterska, Wydział Prawa Kanonicznego Uniwersytetu Kardynała Stefana Wyszyńskiego, Warszawa 2020, 9-32.

${ }^{32}$ Por. RS 2001, art. $2 \$ 2$; KPK 1983, kann. 1501-1504. Por. także: J. Punderson, De causis ad secrae ordinationis nullitatem declarandam, w: Comentario exegetico al Código de Derecho Canónico, VI/2, 2020; L. NAvarro, Nuovo regolamento per avviare e celebrare il procedimento amministrativo di nullità dell'ordinazione. Commento, w: Norme procedurali canoniche commentate, a cura di M. Del Pozzo - J. Llobell - J. Miñabres, Coletti a San Pietro, Roma 2013, 242.

${ }^{33}$ Por. RS 2001, art. $2 \$ 2$. Według przepisów z 1931 roku przeprowadzenie dochodzenia pozasądowego zlecała ordynariuszowi Kongregacja Sakramentów (por. RS 1931, n. $6 \$ 1$ ). Pisze o tym: L. NAVARro, Le nuove regulae servandae per le cause di nullità della sacra ordinazione, Ius Ecclesiae 15/1 (2003) 330-331. 
domniemywa się, że dochodzenie pozasądowe zostało już przez nich przeprowadzone i że ujawnił się fumus boni iuris ${ }^{34}$.

Z chwilą przesłania skargi do Urzędu Administracyjnego przy Rocie Rzymskiej zabrania się duchownemu - na mocy samego prawa - wykonywania czynności wynikających z władzy święceń ${ }^{35}$, o czym ordynariusz, któremu duchowny przekazał pismo skargowe, powinien poinformować go o wspomnianym skutku pomimo tego, że zakaz następuje ipso iure. Jeśli pismo skargowe wnosi ordynariusz albo rzecznik sprawiedliwości, wówczas zakaz obowiązuje duchownego od momentu otrzymania od nich stosownej informacji. Celem tego zakazu, którego nie można mylić z karą, jest ochrona czynności wynikających $\mathrm{z}$ władzy święcen' ${ }^{36}$. Autorzy dodają, że jeśli duchowny ma poważne wątpliwości dotyczące ważności swoich święceń, sam powinien w sumieniu zaprzestać wykonywania władzy święceń, a gdyby z kolei ordynariusz miał uzasadnione podejrzenie o nieważności święceń duchowego, powinien ad cautelam zakazać mu wykonywania władzy święceń, wydając - zgodnie z kan. 49 - odpowiedni nakaz (praeceptum singulare) ${ }^{37}$. Do wydanego zakazu może ponadto dołączyć sankcje karne na wypadek niepodporządkowania się duchownego zakazowi ${ }^{38}$.

\footnotetext{
${ }^{34}$ Por. L. Navarro, Nuovo regolamento per avviare e celebrare il procedimento amministrativo di nullità dell'ordinazione. Commento, w: Norme procedurali canoniche commentate, 242.

${ }^{35}$ Por. KPK 1983, kan. $1709 \$ 2$.

${ }^{36}$ Por. L. Navarro, Nulidad de la sagrada ordenación [causas de], w: Dicionario General de Derecho Canónico, V, dir. J. Otaduy - A. Viana - J. Sedano, Editorial Aranzadi, Pamplona 2012, 600.

${ }^{37}$ Por. J. Punderson, De causis ad secrae ordinationis nullitatem declarandam, w: Comentario exegético al Código de Derecho Canónico, VI/2, 2022; L. NAvarro, Nuovo regolamento per avviare e celebrare il procedimento amministrativo di nullità dell'ordinazione. Commento, w: Norme procedurali canoniche commentate, 242. Por. także: A. GonzÀlez Martín, La nulidad de la sagrada ordenación, Ius Canonicum 23 (1983) 592; M. SтокŁosA, Utrata stanu duchownego w aktualnym prawodawstwie Kościoła łacińskiego, 20.

${ }^{38}$ Por. KPK 1983, kan. 1319. Por. także: J. Punderson, De causis ad secrae ordinationis nullitatem declarandam, w: Comentario exegetico al Código de Derecho
} 
Skarga (actio) w sprawie nieważności święceń dotyczy stanu osób i dlatego nigdy nie wygasa przez przedawnienie ${ }^{39}$ i nie przechodzi w stan rzeczy osądzonej ${ }^{40}$, co powoduje, że nawet jeśli wydane orzeczenie stało się prawomocne, zawsze można prosić o novae causae propositio, o ile istnieją nowe i poważne dowody albo argumenty ${ }^{41}$.

\section{Postepowanie}

Urząd Administracyjny przy Rocie Rzymskiej po otrzymaniu pisma skargowego zbada je od strony formalnej i materialnej. Jeśli brakuje fumus boni iuris, dziekan Roty Rzymskiej, jako kierownik tegoż Urzędu, odrzuci przedłożone pismo skargowe, a wtedy petent ma dziesięć dni użytecznych, liczonych od momentu otrzymania pisma kierownika Urzędu, na wniesienie prośby o odwołanie lub zmianę decyzji ${ }^{42}$. W przypadku braków formalnych powstałemu problemowi można stosunkowo łatwo zaradzić wnosząc ponownie poprawione pismo skargowe ${ }^{43}$. J. Punderson zaznacza, że gdyby natomiast odrzucenie skargi naruszało przepisy prawa materialnego lub formalnego, może on - w ciągu sześćdziesięciu dni użytecznych - wnieść stosowny rekurs do Najwyższego Trybunału Sygnatury Apostolskiej ${ }^{44}$.

\footnotetext{
Canónico, VI/2, 2022.

${ }^{39}$ Por. KPK 1983, kan. $1492 \S 1$.

${ }^{40}$ Por. tamże, kan. 1643.

${ }^{41}$ Por. tamże, kan. $1644 \$ 1$. Na ten temat por.: J. Punderson, De causis ad secrae ordinationis nullitatem declarandam, w: Comentario exegetico al Código de Derecho Canónico, VI/2, 2024; A. Mizıński, Proces o stwierdzenie nieważności święceń w aktualnych przepisach Kościoła łacińskiego, Roczniki Nauk Prawnych 22/4 (2012) 175; M. SтокŁosA, Utrata stanu duchownego w aktualnym prawodawstwie Kościoła łacińskiego, 20.

${ }^{42}$ Por. Segreteria Di Stato, Regolamento Generale della Curia Romana, 30.04.1999, artt. $134 \$ 2$ i $135 \$ 1$, w: AAS 91 (1999) 683.

${ }^{43}$ Por. KPK 1983, kan. $1505 \$ 3$. Por.: J. Punderson, De causis ad secrae ordinationis nullitatem declarandam, w: Comentario exegetico al Código de Derecho Canónico, $\mathrm{VI} / 2,2022$.

${ }^{44}$ Por. Segreteria Di Stato, Regolamento generale della Curia Romana, 30.04.1999, artt. $135 \$ 2$ i $136 \$ 4$; PB art. $123 \$ 1$; Benedictus XVI, Lex propria Supremi Tribunalis Signaturae Apostolicae, 21.06.2008, art. $34 \$ 1$, w: EV, XXV, 634.
} 
Przyjmując pismo skargowe kierownik Urzędu musi zadecydować, czy sprawa o nieważność święceń ma być przeprowadzona przez tenże Urząd na drodze administracyjnej, czy też ma wyznaczyć trybunał zwyczajny, któremu powierzy przeprowadzenie procesu sądowego ${ }^{45}$. Dotychczasowa praktyka Stolicy Apostolskiej w tym zakresie pokazuje, że sprawy o nieważność święceń były zazwyczaj rozpatrywane na drodze administracyjnej, po uprzednim przeprowadzeniu instrukcji sprawy przez kompetentnego ordynariusza ${ }^{46}$. Regulae servandae z 2001 roku nie wskazują żadnych kryteriów, jakimi powinien kierować się dziekan Roty Rzymskiej jako kierownik Urzędu Administracyjnego w podejmowaniu decyzji dotyczącej zasadności wyboru postępowania administracyjnego albo sądowego ${ }^{47}$.

\subsection{Postępowanie przed ordynariuszem}

Zadaniem ordynariusza w postępowaniu administracyjnym jest przeprowadzenie instrukcji sprawy oraz przekazanie odpowiednio przygotowanych akt tegoż postępowania do Urzędu Administracyjnego przy Rocie Rzymskiej celem rozstrzygnięcia sprawy o nieważność święceń. Aby tak się stało, należy powołać odpowiednich urzędników.

Por. także: J. Punderson, De causis ad secrae ordinationis nullitatem declarandam, w: Comentario exegetico al Código de Derecho Canónico, VI/2, 2021.

${ }_{5}$ „Skarga powodowa winna być przesłana do właściwej Kongregacji, która decyduje, czy sprawa ma być prowadzona przez samą Kongregację Kurii Rzymskiej, czy też przez wyznaczony przez nią trybunał” (KPK 1983, kan. $1709 \$ 1$ ).

${ }^{46}$ Szerzej na ten temat: J. Punderson, De causis ad secrae ordinationis nullitatem declarandam, w: Comentario exegetico al Código de Derecho Canónico, VI/2, 2022; L. NAVARRo, Le nuove regulae servandae per le cause di nullità della sacra ordinazione, Ius Ecclesiae 15/1 (2003) 316, przypis n. 9.

${ }^{47}$ Por. P. Amenta, La nuova normativa per lo svolgimento delle cause di dichiarazione di nullità dell'ordinazione: commento e primi rilievi, Folia Canonica 5 (2002) 173. 


\subsubsection{Mianowanie urzędników}

Jeśli ordynariusz zostanie upoważniony przez kierownika Urzędu Administracyjnego do przeprowadzenia instrukcji sprawy, powinien jak najszybciej powołać urzędników do wykonania tego zadania, mianowicie: instruktora sprawy, obrońcę święceń i notariusza ${ }^{48}$.

W odniesieniu do instruktora sprawy i obrońcy święceń Regulae servandae z 2001 roku wyraźnie mówią, że ordynariusz powinien ich mianować spośród urzędników trybunału albo kurii diecezjalnej, ale jednocześnie dodaje, że - za wyjątkiem szczególnych racji - można mianować kogokolwiek pod warunkiem, iż spełnia on wymagania stawiane przez prawo poszczególnym urzędom ${ }^{49}$. Wydaje się, że w myśl zasady odnoszącej się do notariusza w sprawach dotyczących kapłana, obydwaj powinni być kapłanami ${ }^{50}$. L. Navarro sugeruje, aby w dekrecie nominacyjnym zaznaczyć, iż mianowanie obydwu urzędników odbywa się z zachowaniem przepisów artt. 3 i 4 zawartych w Regule servandae $\mathrm{z} 2001 \mathrm{roku}^{51}$.

Ordynariusz musi koniecznie mianować także notariusza, którym - mając na uwadze przedmiot postępowania - powinien być

\footnotetext{
${ }^{48}$ Por. RS 2001, art. $3 \$ 1$.

${ }^{49}$ Por. tamże. W odniesieniu do instruktora sprawy ustawodawca kościelny wymaga spełnienia warunków, jakie są stawiane sędziemu: „\$1. W diecezji biskup powinien ustanowić sędziów diecezjalnych, którymi powinni być duchowni. $\$ 3$. Sędziowie winni być nienaruszonej sławy i doktorami lub przynajmniej licencjatami prawa kanonicznego" (KPK 1983, kan. 1421). Natomiast od obrońcy węzła oczekuje, aby spełnił zadanie, jakie do niego należy w sprawach o nieważność święceń: „Dla spraw, w których chodzi o nieważność święceń (...) należy ustanowić w diecezji obrońcę węzła, którego obowiązkiem jest proponować i przedstawiać wszystko, co w sposób rozumny może być przytoczone przeciw nieważności (...)” (tamże, kan. 1432).

${ }^{50}$ Por. tamże, kan. $483 \$ 2$. Tak uważają m.in.: J. Punderson, De causis ad secrae ordinationis nullitatem declarandam, w: Comentario exegetico al Código de Derecho Canónico, VI/2, 2024-2025; L. NAVARro, Nuovo regolamento per avviare e celebrare il procedimento amministrativo di nullità dell'ordinazione. Commento, w: Norme procedurali canoniche commentate, 243.

${ }^{51}$ Por. tamże.
} 
$\operatorname{kapłan}^{52}$ cieszący się dobrą opinią i wolny od wszelkich podejrzeń ${ }^{53}$. Notariusz powinien brać udział w instrukcji sprawy, a sporządzone przez niego akta są publicznie wiarygodne; brak jego podpisu w aktach postępowania powoduje ich nieważnośćs4.

Wszystkie nominacje powinny być dokonane na piśmie, a stosowne dokumenty należy włączyć do akt instrukcji sprawy ${ }^{55}$.

Regule servandae zaznaczają, że ordynariusz może wprawdzie osobiście przeprowadzić instrukcję sprawy, ale jednocześnie odradzają mu dokonywania tego w przypadkach zwyczajnych ${ }^{56}$, aby zagwarantować niezależność w przeprowadzeniu tejże instrukcji ${ }^{57}$. Tymi samymi motywami kierują się przepisy, które dodają, że ani ordynariusz, ani instruktor sprawy nie powinni podejmować się przeprowadzenia instrukcji, jeśli petent jest $\mathrm{z}$ nimi spokrewniony, spowinowacony albo pozostaje w wielkiej zażyłości lub niechęci ${ }^{58}$. Uwzględniając zakres pokrewieństwa i powinowactwa, można kierować się kryteriami wskazanymi w kan. 1448, który - w odniesieniu do sędziego kościelnego - mówi o jakimkolwiek stopniu w linii prostej i o czwartym stopniu w linii bocznej ${ }^{59}$. W myśl kan. $1448 \$ 2$ te same kryteria powinny mieć zastosowanie w odniesieniu do obrońcy święceń, co przewidywały przepisy z 1931 roku $^{60}$. Gdyby w takich okolicznościach ordynariusz albo instruktor lub/i obrońca święceń sami nie wycofali się z przeprowadzenia

\footnotetext{
${ }^{52}$ Por. KPK 1983, kan. $483 \$ 2$. Wyraźnie o tym mówi: RS 2001, art. $8 \S 2$.

${ }^{53}$ Por. tamże.

${ }^{54}$ Por. KPK 1983, kan. $1437 \S \$ 1-2$; RS 2001, art. 14.

${ }^{55}$ Por. tamże, art. $3 \$ 2$.

${ }^{56}$ Por. tamże.

${ }^{57}$ Por. L. Navarro, Nuovo regolamento per avviare e celebrare il procedimento amministrativo di nullità dell'ordinazione. Commento, w: Norme procedurali canoniche commentate, 243.

${ }^{58}$ Por. RS 2001, art. 4. Por. także: KPK 1983, kan. $1448 \$ 1$.

${ }^{59}$ Por. L. NAvarro, Nuovo regolamento per avviare e celebrare il procedimento amministrativo di nullità dell'ordinazione. Commento, w: Norme procedurali canoniche commentate, 243.

${ }^{60}$ Por. RS 1931, art. $8 \$ 2$. Zwraca na to uwagę L. NAVARro, Nuovo regolamento per avviare e celebrare il procedimento amministrativo di nullità dell'ordinazione. Commento, w: Norme procedurali canoniche commentate, 243.
} 
instrukcji sprawy, wtedy petent może wnieść wniosek o ich wyłączenie. Wówczas - w myśl zasady kodeksowej - ordynariusz powinien powstrzymać się od prowadzenia instrukcji ${ }^{61}$, sprawę instruktora rozstrzyga ordynariusz ${ }^{62}$, a sprawę obrońcy święceń rozstrzyga instruktor ${ }^{63}$, wyznaczając - o ile zarzuty są uzasadnione - nowych urzędników ${ }^{64}$. Należy o tym wspomnieć w aktach postępowania ${ }^{65}$.

Stolica Apostolska oczekuje, aby instrukcja sprawy została szybko przeprowadzona, i dlatego postanawia, że zarówno ordynariusz, jak i instruktor sprawy, mogą z kolei mianować inne odpowiednie osoby, które zastąpią instruktora lub innych urzędników w konkretnych przypadkach, jeśli mieliby oni jakąś przeszkodę ${ }^{66}$. Należy o tym wspomnieć $\mathrm{w}$ aktach postępowania ${ }^{67}$.

\subsubsection{Obowiązki i prawa instruktora sprawy i obrońcy święceń}

Regulae servandae z 2001 roku wskazują obowiązki i prawa, jakie - w związku z instrukcją sprawy związaną z administracyjnym orzeczeniem nieważności święceń - należą do instruktora sprawy i obrońcy święceń.

\subsubsection{Obowiązki i prawa instruktora sprawy}

Instruktor sprawy jest odpowiedzialny za właściwe zebranie środków dowodowych w sprawie nieważności święceń, aby w tej kwestii można było uzyskać pewność moralną. W tym celu przepisy prawa dają mu szerokie uprawnienia ${ }^{68}$. Do jego szczegółowych obowiązków i praw należą m.in.:

\footnotetext{
${ }^{61}$ Por. tamże, kan. $1449 \S 3$.

${ }^{62}$ Por. tamże, kan. $1449 \$ 2$.

${ }^{63}$ Por. tamże, kan. $1449 \$ 4$.

${ }^{64}$ Por. RS 2001, art. 5.

${ }^{65}$ Por. tamże.

${ }^{66}$ Por. tamże.

${ }^{67}$ Por. tamże.

${ }^{68}$ Por. L. NAvarro, Nuovo regolamento per avviare e celebrare il procedimento amministrativo di nullità dell'ordinazione. Commento, w: Norme procedurali canoniche commentate, 244 .
} 
- przeprowadzenie instrukcji sprawy w odniesieniu do wszystkiego, co może dowodzić nieważności święceń w konkretnym przypadku $^{69}$;

- poinformowanie petenta, przed rozpoczęciem instrukcji sprawy, o możliwości ustanowienia sobie pełnomocnika, którym powinien być kapłan odznaczający się prawością i przede wszystkim wiedzą z zakresu prawa kanonicznego i teologii ${ }^{70}$;

- przesłuchanie petenta i świadków, stawiając im pytania przygotowane uprzednio przez obrońcę święceń ${ }^{71}$. Niezależnie od tego petent może, o ile uzna to za konieczne, osobiście albo przez pełnomocnika, przedstawić pewne kwestie wszystkim albo niektórym świadkom ${ }^{72}$;

- skorzystanie z pomocy innego ordynariusza miejsca, jeśli petent albo świadkowie należą do jego diecezji albo przebywają poza swoją diecezją i nie mogą stawić się w wyznaczonym miejscu w celu złożenia oświadczeń i zeznań z powodu odległości albo innej przeszkody (np. choroba, odbywanie kary pozbawienia wolności) ${ }^{73}$. W takiej sytuacji będzie miało zastosowanie postępowanie rogatoryjne, $\mathrm{w}$ którym ordynariusz miejsca mianuje kapłanów do wypełnienia funkcji instruktora i notariusza, z zachowaniem przepisów prawa oraz wytycznych otrzymanych od instruktora sprawy i zgodnie z załączonymi przez niego pytaniami przygotowanymi przez obrońcę święcen ${ }^{74}$;

${ }^{69}$ Por. RS 2001, art. $6 \$ 1$.

${ }^{70}$ Por. tamże, art. $6 \$ 3$.

${ }^{71}$ Por. tamże, art. $6 \$ 3$.

${ }^{72}$ Por. tamże, art. 7.

${ }^{73}$ Por. tamże, art. $8 \$ 1$. Por. także: L. Navarro, Nuovo regolamento per avviare e celebrare il procedimento amministrativo di nullità dell'ordinazione. Commento, w: Norme procedurali canoniche commentate, 246; M. SтокŁosA, Utrata stanu duchownego w aktualnym prawodawstwie Kościoła łacińskiego, 23.

${ }^{74}$ Por. RS 2001, art. $8 \$ 1$. Por. także: L. NAVARRO, Nuovo regolamento per avviare e celebrare il procedimento amministrativo di nullità dell'ordinazione. Commento, 
- przesłuchanie petenta i/albo świadków za pośrednictwem proboszcza lub innego odpowiedniego kapłana delegowanego przez siebie, jeśli duchowny albo świadek mieszkają wprawdzie na terenie diecezji, ale nie mogą się przed nim stawić z powodu odległości lub innej poważnej przyczyny, a także sam instruktor sprawy oraz obrońca święceń i notariusz nie mogą się udać do miejsca ich pobytu ${ }^{75}$. W tych przypadkach delegowani kapłani mogą sobie dobrać innych odpowiednich kapłanów do pełnienia funkcji notariusza ${ }^{76}$. Delegowanemu kapłanowi instruktor powinien przesłać niezbędne wytyczne, pytania oraz dokumenty dotyczące sprawy ${ }^{77}$;

- zbadanie uczciwości i wiarygodności każdego wezwanego, zarówno petenta, jak i świadków. Środkiem do tego ma być m.in. świadectwo ich proboszcza. O tego rodzaju działaniach - mających na celu ocenę mocy dowodowej środka dowodowego - należy zaznaczyć w aktach postępowania ${ }^{78}$;

- możliwość odstąpienia od przepisu zawartego w Regulae servandae z 2001 roku, o ile w konkretnej sytuacji zachodzi słuszna przyczyna, i wskazanie w aktach instrukcji sprawy przyczyny niezachowania tegoż przepisu ${ }^{79}$.

w: Norme procedurali canoniche commentate, 246; M. SтокŁоsA, Utrata stanu duchownego w aktualnym prawodawstwie Kościoła łacińskiego, 23.

${ }^{75}$ Por. RS 2001, art. $8 \$ 2$.

${ }^{76}$ Por. tamże. Por. także: L. NAVArro, Nuovo regolamento per avviare e celebrare il procedimento amministrativo di nullità dell'ordinazione. Commento, w: Norme procedurali canoniche commentate, 246; M. STOKŁosA, Utrata stanu duchownego w aktualnym prawodawstwie Kościoła łacińskiego, 23.

${ }^{77}$ Por. RS 2001, art. $8 \$ 2$.

${ }^{78}$ Por. tamże, art. 9. Por. także: L. NAVARro, Nuovo regolamento per avviare e celebrare il procedimento amministrativo di nullità dell'ordinazione. Commento, w: Norme procedurali canoniche commentate, 247.

${ }^{79}$ Por. RS 2001, art. $22 \$ 1$. Por. także: P. Amenta, La nuova normativa per lo svolgimento delle cause di dichiarazione di nullità dell'ordinazione: commento e primi rilievi, Folia Canonica 5 (2002) 176. 


\subsubsection{Obowiązki i prawa obrońcy święceń}

Do obowiązków obrońcy święceń, w trakcie instrukcji sprawy, Regulae servandae z 16 października 2001 roku zaliczają m.in.:

opracowanie i przedstawienie instruktorowi sprawy w zamkniętej kopercie podpisanych pytań dla petenta i świadków i ewentualne zasugerowanie dla nich nowych pytań wynikłych z przesłuchań, zwłaszcza w przypadku sprzecznych oświadczeń, zeznań, świadectw ${ }^{80}$.

- obecność podczas składania oświadczeń przez petenta i zeznań przez świadków albo przynajmniej przeglądnięcie ich w siedzibie trybunału i wyrażenie swojej opinii ${ }^{81}$;

- dokładne rozważenie artykułów (kwestie mające być przedmiotem pytań) zaproponowanych przez petenta ${ }^{82}$ i zbadanie autentyczności dokumentów przez niego przedstawionych ${ }^{83}$;

- $\quad$ przygotowanie na piśmie uwag (animadversiones) do zebranego materiału dowodowego i przedstawienie wszystkiego, co uważa za użyteczne dla ochrony święceń ${ }^{84}$;

- odwołanie się do instruktora sprawy w każdym przypadku, w którym dopatrzył się naruszenia sprawiedliwości i prawa petenta albo bezprawnego pominięcia czegoś, albo podjęcia działania niewskazanego, albo pominięcia jakiegoś przepisu prawa. Gdyby w tego rodzaju przypadkach, powodujących negatywne skutki dla sprawy, instruktor nie podzielał stanowiska obrońcy święceń, ten ostatni może odwołać się (recursus) do ordynariusza, który im powierzył przeprowadzenie instrukcji sprawy ${ }^{85}$. P. Amenta i L. Navarro słusznie zauważają,

\footnotetext{
${ }^{80}$ Por. RS 2001, art. $\left.10 \$ 1, \mathrm{~b}\right)$.

${ }^{81}$ Por. tamże, art. $10 \$ 1$ a); KPK 1983, kan. 1433.

${ }^{82}$ Por. RS 2001, artt. $10 \$ 1$, b) i 7. Szerzej na temat artykułów: F. Gil De Las Heras, Artículos para el interrogatorio, w: Diccionario General de Derecho Canónico, I, dir. J. Otaduy - A. Viana - J. Sedano, Editorial Aranzadi, Pamplona 2012, 480-481.

${ }^{83}$ Por. RS 2001, art. $10 \$ 1, \mathrm{c}$ ).

${ }^{84}$ Por. tamże, art. $10 \$ 1$, d); KPK 1983, kan. 1432.

${ }^{85}$ Por. RS 2001, art. $10 \$ 2$. Por także: L. NAVARRo, Nuovo regolamento per avviare e celebrare il procedimento amministrativo di nullità dell'ordinazione. Commento,
} 
że w takich okolicznościach obrońca węzła wydaje się spełniać także zadania rzecznika sprawiedliwości ${ }^{86}$.

\subsubsection{Odpowiedzialność ordynariusza}

Mianowanie urzędników do przeprowadzenia instrukcji sprawy w żaden sposób nie zwalnia ordynariusza z odpowiedzialności za zgodne z prawem zebranie środków dowodowych dotyczących nieważności święceń. Co więcej, Regulae servandae z 2001 roku bardzo mocno podkreślają, że zachowanie zawartych w nich przepisów jest w bardzo szczególny sposób powierzone ordynariuszowi i stąd jego obowiązkiem jest czuwanie, aby wyznaczeni przez niego urzędnicy wiernie je przestrzegali. $\mathrm{Z}$ tego względu ordynariusz ma prawo, stosownie do swojego uznania, na każdym etapie instrukcji sprawy, zbadać akta postępowania, udzielać wyznaczonym urzędnikom rad i wskazówek, odsunąć ich od powierzonego im zadania, o ile istnieje ku temu poważna przyczyna ${ }^{87}$, rozpatrywać skierowane do niego rekursy ${ }^{88}$ czy wyrażać zgodę na konkretny sposób postępowania przez instruktora w określonej kwestii ${ }^{89}$.

\subsubsection{Przebieg instrukcji sprawy}

Zanim instruktor rozpocznie zbieranie środków dowodowych, jest zobowiązany przez Regulae servandae z 2001 roku do poinformowania petenta o prawie do ustanowienia sobie pełnomocnika, którym musi być kapłan szanowany ze względu na swoją uczciwość

w: Norme procedurali canoniche commentate, 247; M. SтокŁosA, Utrata stanu duchownego w aktualnym prawodawstwie Kościoła łacińskiego, 25.

${ }^{86}$ Por. P. Amenta, La nuova normativa per lo svolgimento delle cause di dichiarazione di nullità dell'ordinazione: commento e primi rilievi, Folia Canonica 5 (2002) 175; L. NAVARro, Nuovo regolamento per avviare e celebrare il procedimento amministrativo di nullità dell'ordinazione. Commento, w: Norme procedurali canoniche commentate, 249.

${ }^{87}$ Por. tamże, art. $22 \$ 2$.

${ }^{88}$ Por. RS 2001, art. $10 \$ 2$ i art. 16.

${ }^{89}$ Por. tamże, art. $11 \S 1$. 
i przede wszystkim ze względu na swoją wiedzę prawną i teologiczną ${ }^{90}$. Pełnomocnik, którego pełnomocnictwo musi być załączone do akt postępowania, nie jest adwokatem, lecz raczej doradcą prawnym petenta, działającym w jego imieniu i w jego interesie ${ }^{91}$.

Przystępując do instrukcji sprawy, instruktor powinien uwzględnić środki dowodowe, jakie wskazują wyżej wspomniane przepisy, w zależności od wskazanego tytułu nieważności święceń, mianowicie: zaprzysiężone oświadczenie petenta ${ }^{92}$; zaprzysiężone zeznania świadków ${ }^{93}$, a wśród nich świadkowie przedstawieni przez petenta i świadkowie z urzędu ${ }^{94}$, zwłaszcza członkowie rodziny duchownego ${ }^{95}$, wychowawcy w seminarium ${ }^{96}$ czy w domu formacyjnym instytutu zakonnego (nowicjat), koledzy $\mathrm{z}$ okresu formacji i osoby zaprzyjaźnione $^{97}$; jakiekolwiek autentyczne dokumenty (publiczne i prywatne $)^{98}$, jak zaświadczenia (attestationes) ${ }^{99}$, listy i inne pisma dotyczące sprawy ${ }^{100}$; opinie biegłych; poszlaki i domniemania ${ }^{101}$, czyli fakty dotyczące życia oraz inne okoliczności zaistniałe przed, w czasie

\footnotetext{
${ }^{90}$ Por. tamże, art. $6 \$ 1$.

${ }^{91}$ Por. P. Amenta, La nuova normativa per lo svolgimento delle cause di dichiarazione di nullità dell'ordinazione: commento e primi rilievi, Folia Canonica 5 (2002) 175 ; L. NAVARro, Nuovo regolamento per avviare e celebrare il procedimento amministrativo di nullità dell'ordinazione. Commento, w: Norme procedurali canoniche commentate, 245.

${ }^{92}$ Por. RS 2001, art. $6 \$ 2$, a).

${ }^{93}$ Por. tamże, art. $\left.6 \$ 2, b\right)$.

${ }^{94}$ Por. tamże, art. art. $\left.6 \$ 2, \mathrm{c}\right)$.

${ }^{95}$ Por. tamże, art. $\left.6 \$ 2, \mathrm{~b}\right)$.

${ }^{96}$ Por. tamże.

${ }^{97}$ Por. L. Navarro, Nuovo regolamento per avviare e celebrare il procedimento amministrativo di nullità dell'ordinazione. Commento, w: Norme procedurali canoniche commentate, 245.

${ }^{98}$ Por. RS 2001, art. $6 \$ 2$, d).

${ }^{99}$ Por. tamże, art. $17 \$ 2$.

${ }^{100}$ Por. tamże, art. $\left.6 \$ 2, \mathrm{~d}\right)$.

${ }^{101}$ Por. tamże, art. $6 \$ 2$, e).
} 
i po przyjęciu święceń, z których można wnioskować o intencjach, jakimi kierował się duchowny ${ }^{102}$.

\subsubsection{Wezwanie petenta i świadków}

Zarówno petent, jak i każdy ze świadków, muszą być wezwani pisemnie do stawienia się w oznaczonym dniu na sesji w ramach instrukcji sprawy. Stosowne dekrety należy przesłać do zainteresowanych w odpowiednim czasie przed datą stawienia się na sesji ${ }^{103}$. Ustawa nie określa, jaki to ma być czas. Z pewnością taki, aby osoby wezwane miały czas na ewentualne odpowiedzenie i usprawiedliwienie swej nieobecności.

Jeśli, po dokładnym zbadaniu, nieznane jest miejsce pobytu petenta albo/i świadków, instruktor sprawy powinien rozeznać czy należy w tym przypadku zachować zasady wskazane przez Kodeks Prawa Kanonicznego a dotyczące tego rodzaju sytuacji procesowych ${ }^{104}$ czy też, za zgodą ordynariusza, zastosować jeszcze inny odpowiedni sposób wezwania, zgodnie $\mathrm{z}$ uznaniem instruktora ${ }^{105}$. Wydaje się jednak, że jeśli duchowny prosi o stwierdzenie nieważności swoich święceń, to będzie aktywnie współpracował w sprawie, podając

\footnotetext{
${ }^{102}$ Por. L. Navarro, Nuovo regolamento per avviare e celebrare il procedimento amministrativo di nullità dell'ordinazione. Commento, w: Norme procedurali canoniche commentate, 245.

${ }^{103}$ Por. RS 2001, art. $11 \S 1$.

104 “ $\$ 1$. Dekret wezwania przed sąd powinien być zaraz podany do wiadomości stronie pozwanej i wszystkim pozostałym, którzy powinni się stawić.

$\$ 2$. Do pozwu należy dołączyć skargę powodową, chyba że sędzia na skutek poważnych racji dojdzie do wniosku, iż stronie nie należy przekazywać skargi, dopóki nie złoży ona zeznań w sądzie” (kan. 1508).

„\$1. Zawiadomienie o pozwie, dekretach, wyrokach i innych aktach sądowych powinno być dokonane przez pocztę lub w inny sposób, który jest najpewniejszy, z zachowaniem przepisów ustanowionych prawem partykularnym. $\$ 2$. Fakt zawiadomienia i jego sposób należy odnotować w aktach” (kan. 1509).

${ }^{105}$ Por. RS 2001, art. $11 \$ 1$. Na ten temat por.: L. NAvarro, Nuovo regolamento per avviare e celebrare il procedimento amministrativo di nullità dell'ordinazione. Commento, w: Norme procedurali canoniche commentate, 248.
} 
miejsce swego zamieszkania albo pobytu oraz niezbędne dane dotyczące wskazanych przez siebie świadków ${ }^{106}$.

W przypadku odmowy stawienia się wezwanej osoby na przesłuchanie, instruktor powinien zastanowić się, czy nie ponowić wezwania i nie zastosować innych bardziej sprzyjających sposobów przekazania wezwania do stawienia się przed instruktorem, np. skorzystanie z pośrednictwa osoby zaprzyjaźnionej albo godnej zaufania ${ }^{107}$.

\subsubsection{Oświadczenia petenta i zeznania świadków}

Petent i każdy świadek, zanim rozpoczną składać swoje zeznania, muszą najpierw złożyć przysięgę mówienia prawdy. Złożenie przysięgi dokonuje się poprzez wypowiedzenie stosownej formuły i dotknięcie ręką Ewangelii. Gdyby świadek odmówił złożenia przysięgi, należy odnotować w aktach sprawy fakt odmowy oraz motywy ${ }^{108}$. W takich okolicznościach można zaproponować mu złożenie przyrzeczenia mówienia prawdy ${ }^{109}$.Zarówno petenta, jak i świadków, należy powiadomić o znaczeniu przysięgi oraz o ewentualnych sankcjach karnych przewidzianych w Kościele za krzywoprzysięstwo ${ }^{110}$.

W odniesieniu do sposobu przesłuchiwania Regulae servandae z 2001 roku wyjaśniają, że petent i świadkowie odpowiadają ustnie

\footnotetext{
${ }^{106}$ Por. tamże.

${ }^{107}$ Por. RS 2001, art. $11 \S 2$.

${ }^{108}$ Por. tamże, art. 12 oraz art. $6 \$ 2$ a) i b).

${ }^{109}$ Por. Pontificium Consilium De Legum Textibus, Dignitas connubii. Instructio servanda a tribunalibus dioecesanis et interdioecesanis in pertractandis causis nullitatis matrimonii, 25.01.2005, art. $167 \$ 2$, Libreria Editrice Vaticana, Città del Vaticano 2005, 62. Przepisy Regulae servandae z 2001 roku nie wspominają o odmowie złożenia przysięgi przez petenta.

${ }^{110}$ Por. RS 2001, art. 12. „Kto stwierdzając lub przyrzekając coś wobec władzy kościelnej dopuszcza się krzywoprzysięstwa, powinien być ukarany sprawiedliwą karą” (kan. 1368). „Stosownie do ciężkości przestępstwa, może być ukarany sprawiedliwą karą: $1^{\circ}$ kto sporządza fałszywy dokument kościelny lub prawdziwy zmienia, niszczy, ukrywa, albo posługuje się fałszywym lub zmienionym;

$2^{\circ}$ kto w sprawie kościelnej posługuje się innym fałszywym lub zmienionym dokumentem;

$3^{\circ}$ kto w publicznym dokumencie kościelnym potwierdza fałsz" (kan. 1391).
} 
jedynie na pytania postawione przez instruktora ${ }^{111}$, przygotowane wcześniej przez obrońcę święceń ${ }^{112}$, $\mathrm{z}$ ewentualnym uwzględnieniem artykułów przedstawionych przez petenta ${ }^{113}$. Zatem obrońca święceń, mając nowe pytania wynikające $z$ analizy dotychczas zebranych środków dowodowych, nie może ich zadawać bezpośrednio duchownemu i świadkom ${ }^{114}$. Przed złożeniem zeznań nie można ich informować o pytaniach, jakie im zostaną zadane, ani nie wolno im udostępniać do przeczytania akt postępowania i dokumentów. Przepisy dopuszczają jednak wyjątek i jeśli instruktor sprawy uzna to za stosowne, może zezwolić, aby osoba zeznająca zapoznała się z bardzo ważnym dokumentem, który mógłby potwierdzić jej stwierdzenia albo pomóc jej w przypomnieniu sobie konkretnych faktów ${ }^{115}$.

Zeznania petenta i świadków muszą być zaprotokołowane przez notariusza, a szczególnie to, co dotyczy istoty sprawy. Instruktor może podjąć decyzję o użyciu rejestratora głosu i zapisie oświadczeń na dostępnych nośnikach, z których tenże zapis można odtworzyć. Wtedy jednak zeznania takie należy w całości dokładnie spisać i po wezwaniu do auli osoby zeznającej udostępnić jej spisany protokół, aby jego treść potwierdziła i podpisała ${ }^{116}$. Jednocześnie przepisy wyraźnie zastrzegają, że nie dopuszcza się - także w szczególnych okolicznościach - stosowania telefonu, faxu i innych środków, które - jak podkreślają Regulae servandae z 2001 roku - nie umożliwiają potwierdzenia tożsamości osoby zeznającej ${ }^{117}$.

\footnotetext{
${ }^{111}$ Por. RS 2001, art. 13.

${ }^{112}$ Por. tamże, art. $10 \$ 1 \mathrm{~b}$ ).

${ }^{113}$ Por. tamże, art. $10 \$ 1 \mathrm{~d}$ ).

${ }^{114}$ Por. L. NAVARro, Nuovo regolamento per avviare e celebrare il procedimento amministrativo di nullità dell'ordinazione. Commento, w: Norme procedurali canoniche commentate, 249.

${ }^{115}$ Por. RS 2001, art. 13.

${ }_{116}$ Por. tamże, art. 14; KPK 1983, kan. $1561 \$ 1$.

${ }^{117}$ Por. RS 2001, art. 14. Por. także: L. NAVARRo, Nuovo regolamento per avviare e celebrare il procedimento amministrativo di nullità dell'ordinazione. Commento, w: Norme procedurali canoniche commentate, 249.
} 
Protokół z każdego przesłuchania podpisuje osoba zeznająca, instruktor sprawy, obrońca święceń (jeśli jest obecny podczas przesłuchania) i notariusz.

Normy przewidują możliwość ponownego wezwania przez instruktora sprawy zarówno petenta, jak i świadków. Może to nastąpić w wyniku wniosku osoby zaskarżającej święcenia, świadków, obrońcy święceń, a także instruktora sprawy ex officio po wysłuchaniu obrońcy święceń ${ }^{118}$. Przedmiotem ponownego przesłuchania może być to, co już wcześniej było treścią oświadczeń i zeznań, nowe fakty dotyczące przedmiotu sprawy, pytania wynikające z prowadzonej instrukcji sprawy ${ }^{119}$, rozbieżności w aktach postępowania, niewystarczające wyjaśnienie ważnych punktów ${ }^{120}$.

Mając na uwadze ocenę wartości dowodowej oświadczeń i poszczególnych zeznań, Regulae servandae wymagają, aby instruktor nigdy nie pominął zbadania uczciwości i wiarygodności świadków, a jako narzędzie tej weryfikacji wskazuje świadectwa kwalifikacyjne wydane przez ich proboszczów, o czym należy wspomnieć w aktach postępowania ${ }^{121}$.

Petent i świadkowie, w związku ze składaniem oświadczeń i zeznań, mają prawo przedłożyć instruktorowi dokumenty, jakimi dysponują, a jakie są związane z przedmiotem instrukcji sprawy ${ }^{122}$.

\footnotetext{
${ }^{118}$ Por. RS 2001, art. $15 \$ 1$.

${ }^{119}$ Por. tamże.

${ }^{120}$ Por. L. NAvArro, Nuovo regolamento per avviare e celebrare il procedimento amministrativo di nullità dell'ordinazione. Commento, w: Norme procedurali canoniche commentate, 250.

${ }^{121}$ Por. RS 2001, art. 9; KPK 1983, kan. 1572 (initium). Por. także: L. NAvArro, Nuovo regolamento per avviare e celebrare il procedimento amministrativo di nullità dell'ordinazione. Commento, w: Norme procedurali canoniche commentate, 247; J. SAn José Prisco, Proceso do nulidad de la sagrada ordenación, Revista Española de Derecho Canónico 70 (2013) 617.

122 Por. RS 2001, art. $17 \$ 1$.
} 


\subsubsection{Uprawnienia petenta wobec świadków}

Petentowi przysługuje prawo do poznania imion i nazwisk świadków wezwanych z urzędu przez instruktora albo na wniosek obrońcy święceń. Jednak instruktor, po wysłuchaniu obrońcy święceń albo na jego prośbę, może wydać dekretem postanowienie o niewyjawianiu petentowi tożsamości świadka ex officio. W dekrecie należy wówczas podać powody podjętej decyzji ${ }^{123}$, od której z kolei przysługuje rekurs do ordynariusza ${ }^{124}$, o czym wspomniano wyżej. Duchowny może także prosić o wykluczenie świadka ex officio, jeśli słuszna przyczyna wykluczenia została wykazana przed jego zeznaniami ${ }^{125}$.

\subsubsection{Dowód z dokumentów}

Dokumenty mogą - jako środki dowodowe - znacząco przyczynić się do poznania prawdy dotyczącej ważności święceń. Regulae servandae z 2001 roku wyjaśniają, że i petent i świadkowie mogą - jak to już zostało wspomniane wyżej - przedstawić instruktorowi dokumenty, jakie posiadają w związku ze sprawą, a zwłaszcza te, które zostały sporządzone w okresie, w którym kwestia nieważności święceń nie była jeszcze podnoszona. Chodzi tutaj głównie o zaświadczenia lekarskie stwierdzające istnienie jakiejś choroby dziedzicznej albo genetycznej, na jaką duchowny cierpiał jeszcze przed przyjęciem święceńn ${ }^{126}$, co z kolei mogło wpłynąć na świadomość i wolność petenta w przyjęciu święceń ${ }^{127}$. Także instruktor sprawy ma prawo zarządzić dekretem

\footnotetext{
${ }^{123}$ Por. tamże, art. 16.

${ }^{124}$ Por. tamże. Por. także: P. Amenta, La nuova normativa per lo svolgimento delle cause di dichiarazione di nullità dell'ordinazione: commento e primi rilievi, Folia Canonica 5 (2002) 175.

${ }^{125}$ Por. RS 2001, art. 16; KPK 1983, kan. 1555. Por. także: L. NAvArro, Nuovo regolamento per avviare e celebrare il procedimento amministrativo di nullità dell'ordinazione. Commento, w: Norme procedurali canoniche commentate, 250.

${ }^{126}$ Por. RS 2001, art. $17 \$ 1$.

${ }^{127}$ Por. L. NAvArro, Nuovo regolamento per avviare e celebrare il procedimento amministrativo di nullità dell'ordinazione. Commento, w: Norme procedurali canoniche commentate, 251; J. SAN José PRISCO, Proceso do nulidad de la sagrada ordenación, Revista Española de Derecho Canónico 70 (2013) 619.
} 
poszukiwanie i udostępnienie dokumentów i zaświadczeń oraz może, w czasie przesłuchiwania petenta i świadków, pytać ich na tematy dotyczące tychże dokumentów ${ }^{128}$.

W instrukcji sprawy należy uwzględnić zarówno autentyczne dokumenty publiczne, jak i prywatne ${ }^{129}$. Pośród nich mogą znaleźć się m.in. zaświadczenia (attestationes) ${ }^{130}$, prośba o dopuszczenie do święceń wraz oświadczeniem stwierdzającym dobrowolne ich przyjęcie ${ }^{131}$, listy i inne pisma dotyczące sprawy ${ }^{132}$, fotografie, nagrania głosowe i wideo.

\subsubsection{Opinie biegłych}

Instruktor sprawy, o ile wymaga tego sprawa ze względu na badany tytuł nieważności święceń, może zwrócić się z prośbą do lekarza specjalisty - psychiatry albo psychologa - aby zbadał duchownego i opracował stosowną opinię $e^{133}$. Regulae servandae z 2001 roku wyjaśniają, że instruktor może do tego zadania mianować, wydanym przez siebie dekretem, osobę wyróżniającą się wiedzą i roztropnością ${ }^{134}$. Mianowanemu biegłemu należy także przekazać pisemne pytania, na które powinien odpowiedzieć w swej eksperckiej opinii. Od biegłego wymaga się, aby złożył przysięgę wiernego wypełniania powierzonego mu zadania i zachowania tajemnicy ${ }^{135}$. Zazwyczaj biegłemu udostępnia się także akta sprawy. Po przeprowadzeniu badania stanu petenta (statum oratoris), wykonanego zgodnie z zasadami właściwymi dla danej dziedziny wiedzy i zgodnie - jak słusznie podkreśla L. Navarro - z zasadami antropologii chrześcijańskiej ${ }^{136}$, biegły po-

\footnotetext{
${ }^{128}$ Por. RS 2001, art. $17 \$ 2$.

${ }^{129}$ Por. KPK 1983, kan. 1540 \$\$1-3.

${ }^{130}$ Por. RS 2001, art. $17 \$ 2$.

${ }^{131}$ Por. KPK 1983, kan. 1036.

${ }_{132}$ Por. RS 2001, art. 6 d).

${ }^{133}$ Por. tamże, art. 18. Por. także: PKP 1983, kan. 1574.

${ }^{134}$ Por. RS 2001, art. 18.

${ }^{135}$ Por. tamże.

${ }^{136}$ Por. L. NAvarro, Nuovo regolamento per avviare e celebrare il procedimento amministrativo di nullità dell'ordinazione. Commento, w: Norme procedurali canoniche commentate, 251.
} 
winien zamieścić w pisemnej opinii wskazówki (indicia) i argumenty (argumenta) z zakresu wiedzy medycznej, które wydają się rodzić wątpliwości albo wykluczać ważność święcen ${ }^{137}$.

\subsubsection{Zakończenie instrukcji sprawy}

Aby instruktor mógł ogłosić zakończenie instrukcji sprawy, muszą być spełnione określone warunki: obrońca święceń powinien oświadczyć, że nie ma już nic do zbadania; duchowny powinien oświadczyć, że nie ma nic do dodania ${ }^{138}$; instruktor sprawy powinien uważnie zbadać osobiście akta sprawy oraz zeznania petenta i świadków, zwracając uwagę na to, czy w aktach postępowania nie ma sprzeczności, dwuznaczności, kwestii niewyjaśnionych ${ }^{139}$. Gdyby się okazało, że istnieją sprzeczności, dwuznaczności albo sprawy niejasne, instruktor sprawy powinien rozważyć, czy celem wyjaśnienia tych kwestii i uzupełnienia instrukcji sprawy nie należałoby ponownie wezwać petenta i świadków. Wymaga to jednak uprzedniego wysłuchania opinii obrońcy święceń ${ }^{140}$.

Stanowiska obrońcy święceń i petenta powinny być odnotowane przez notariusza w aktach postępowania przed ordynariuszem.

Instrukcję sprawy zamyka się poprzez wydanie przez instruktora stosownego dekretu ${ }^{141}$.

\subsubsection{Opinie obrońcy święceń, instruktora sprawy i ordynariusza}

Po zamknięciu instrukcji sprawy wymagane jest jeszcze przygotowanie trzech opinii na temat ważności albo nieważności święceń, na podstawie akt instrukcji sprawy, które następnie będą przydatne w studium sprawy w Urzędzie Administracyjnym przy Rocie Rzymskiej oraz wydanie orzeczenia.

\footnotetext{
${ }^{137}$ Por. tamże.

${ }^{138}$ Por. RS 2001, art. $19 \$ 1$.

${ }^{139}$ Por. tamże, art. $19 \$ 2$.

${ }^{140}$ Por. tamże.

${ }^{141}$ Por. tamże.
} 
Najpierw instruktor sprawy wydaje dekret, którym przekazuje wszystkie akta sprawy obrońcy święceń, aby ten z kolei - po wnikliwym zbadaniu wspomnianych akt - sporządził swoje uwagi dotyczące meritum sprawy (animadversiones), wskazując uzasadnienie prawne i faktyczne, i zaznaczając również, czy podczas instrukcji sprawy zostały zachowane wszystkie przepisy prawa ${ }^{142}$.

Następnie stanowisko w sprawie musi wyrazić pisemnie instruktor sprawy. Jego relacja powinna zawierać ocenę merytoryczną prośby petenta opartą na motywacjach prawych i faktycznych ${ }^{143}$.

Wreszcie swoją opinię w sprawie sporządza ordynariusz, który powołał urzędników do przeprowadzenia instrukcji sprawy, i musi to zrobić także wtedy, kiedy sam pełnił funkcję instruktora ${ }^{144}$. Votum ordynariusza dotyczy zarówno meritum sprawy, ze wskazaniem uzasadnienia prawnego i faktycznego, jak i czynników, które mogłyby - w przypadku orzeczenia nieważności święceń - spowodować niebezpieczeństwo skandalu albo też mogłyby być uznane za nieskuteczne do wywołania takiego skutku ${ }^{145}$.

Gdyby się zdarzyło, że urząd biskupa diecezjalnego wakuje, opinię powinien sporządzić ten, kto go prawnie zastępuje: biskup pomocniczy w charakterze wikariusza generalnego lub biskupiego ${ }^{146}$; biskup koadiutor albo pomocniczy, wikariusz generalny albo biskupi lub inni kapłani według kolejności ustalonej przez ordynariusza w wykazie ${ }^{147}$; administrator diecezji ${ }^{148}$.

\subsubsection{Język stosowany $w$ redagowaniu akt}

W redagowaniu akt sprawy w postępowaniu przed ordynariuszem należy stosować język, jaki jest dopuszczony przez Ogólny Regulamin Kurii Rzymskiej, czyli oficjalny język łaciński albo inny spośród

\footnotetext{
${ }^{142}$ Por. tamże, art. 20.

${ }^{143}$ Por. tamże, art. $21 \$ 1$.

${ }^{144}$ Por. tamże, art. $21 \S 2$.

${ }^{145}$ Por. tamże.

${ }_{146}$ Por. tamże, art. $21 \S 2$; KPK 1983, kan. $409 \$ 2$.

${ }^{147}$ Por. RS 2001, art. $21 \S 2$; KPK 1983, kan. $413 \$ 1$.

${ }^{148}$ Por. RS 2001, art. $21 \S 2$; KPK 1983, kan. 426-427.
} 
najbardziej znanych dzisiaj języków ${ }^{149}$ i stosowanych w codziennej praktyce Kurii Rzymskiej, do których zazwyczaj zaliczają się angielski, francuski, hiszpański, portugalski, włoski $i^{150}$. W przeciwnym wypadku wszystkie akta sprawy należy dokładnie (ad verbum) przetłumaczyć na język łaciński albo na inny język stosowany w Urzędzie Administracyjnym przy Rocie Rzymskiej. Jeśli w dokonywaniu przekładu korzysta się z tłumacza, ma on być wyznaczony przez instruktora sprawy, po uprzednim wysłuchaniu opinii obrońcy święceń. Przepisy wymagają także, aby tłumacz złożył przysięgę wiernego wykonania powierzonego mu zadania i zachowania tajemnicy ${ }^{151}$.

\subsubsection{Przygotowanie akt postępowania do przesłania do Stolicy Apostolskiej}

Po zamknięciu instrukcji sprawy, sporządzeniu trzech wyżej wspomnianych opinii i ewentualnego tłumaczenia akt, należy wszystkie akta postępowania, zarówno dotyczące meritum sprawy, czyli akta sprawy, jak i dotyczące procedury, czyli akta procesu ${ }^{152}$, odpowiednio uporządkować, poszczególne karty ponumerować i sporządzić dokładny spis treści, z parafą i pieczęcią notariusza na każdej karcie. Odnosi się to zarówno do akt oryginalnych, jak i do ewentualnego tłumaczenia. Jeżeli akta oryginalne zostały przygotowane w języku stosowanym w Urzędzie Administracyjnym przy Rocie Rzymskiej, wówczas - oprócz oryginału - trzeba jeszcze przygotować jego trzy uwierzytelnione kopie. Gdyby natomiast akta oryginalne zostały przygotowane w języku, który nie jest stosowany w Urzędzie Administracyjnym przy Rocie Rzymskiej, wtedy - oprócz oryginału akt trzeba przygotować jedną uwierzytelnioną kopię oryginału i cztery kopie dokładnego tłumaczenia akt. Każdy egzemplarz powinien być

${ }^{149}$ Por. RS 2001, art. $15 \$ 2$; Segreteria Di Stato, Regolamento Generale della Curia Romana, 30.04.1999, art. $144 \$ 1$; PB art. 16.

${ }^{150}$ Por. L. Navarro, Nuovo regolamento per avviare e celebrare il procedimento amministrativo di nullità dell'ordinazione. Commento, w: Norme procedurali canoniche commentate, 250; M. SтокŁosA, Utrata stanu duchownego w aktualnym prawodawstwie Kościoła łacińskiego, 26.

${ }^{151}$ Por. RS 2001, art. $15 \$ 2$.

${ }^{152}$ Por. KPK 1983, kan. 1472. 
wydany drukiem (wydruk komputerowy lub maszynopis), opatrzony - jak już wcześniej wspomniano - spisem treści i odpowiednio oprawiony (confecto fasciculo typis edito) ${ }^{153}$.

\subsubsection{Przesłanie akt do Stolicy Apostolskiej}

Jeśli tłumaczenie akt na inny język nie jest konieczne, wtedy do Urzędu Administracyjnego przy Rocie Rzymskiej należy przesłać trzy uwierzytelnione kopie akt oryginalnych (in triplici exemplari autentico), natomiast do archiwum kurii ordynariusza należy przekazać akta oryginalne. W przypadku, kiedy akta sprawy były tłumaczone na inny język, wówczas do Stolicy Apostolskiej należy przesłać jedną uwierzytelniona kopię akt oryginalnych i trzy uwierzytelnione kopie ich tłumaczenia ${ }^{154}$, a do kurii ordynariusza przekazuje się akta oryginalne i jedną uwierzytelnioną kopię ich tłumaczenia.

Regulae servandae z 2001 roku wyjaśniają, że przesłanie akt postępowania przed ordynariuszem do Urzędu Administracyjnego przy Rocie Rzymskiej powinno nastąpić za pośrednictwem papieskiego przedstawiciela (nuncjusz, pro-nuncjusz). Gdyby takiego nie było w inny sposób, z zachowaniem ostrożności, jaka jest wymagana dla zabezpieczenia przesłania dokumentów ze względu na konkretne miejscowe uwarunkowania ${ }^{155}$.

\subsection{Postępowanie w Urzędzie Administracyjnym przy Rocie Rzymskiej}

Regulae servandae $\mathrm{z} 2001$ roku, w odróżnieniu od podobnych norm z 1931 roku, zawierają przepisy regulujące postępowanie na etapie rzymskim, włącznie z zagadnieniem dotyczącym zaskarżenia wydanego orzeczenia w sprawie nieważności święceń. P. Amenta uważa, że jest to przejawem dzisiejszego ducha ochrony praw wiernych, dzięki

\footnotetext{
${ }^{153}$ Por. RS 2001, art. 23.

${ }^{154}$ Por. tamże, artt. $15 \$ 2$ i 23.

${ }^{155}$ Por. tamże, art. 23.
} 
czemu zainteresowany duchowny - wnosząc pismo skargowe - może także poznać przepisy, jakie będą stosowane w jego sprawie ${ }^{156}$.

\subsubsection{Powołanie urzędników do konkretnej sprawy}

Po wpłynięciu akt postępowania przed ordynariuszem do Urzędu Administracyjnego przy Rocie Rzymskiej, dziekan Roty - jako kierownik Urzędu - powinien jak najszybciej (quam primum) wyznaczyć urzędników, którzy będą zaangażowani w dalszym procedowaniu sprawy. Należą do nich: trzej komisarze tworzący kolegium - ustanowieni spośród członków specjalnej komisji w Urzędzie Administracyjnym przy Rocie Rzymskiej do rozpatrywania spraw dotyczących orzekania nieważności święceń - z których jednemu należy powierzyć funkcję przewodniczącego kolegium i ponensa sprawy ${ }^{157}$; obrońca święceń mianowany spośród członków wspomnianej komisji albo, według uznania dziekana Roty, spośród urzędników Roty Rzymskiej ${ }^{158}$; jednego lub więcej notariuszy, których można powołać spośród urzędników Urzędu Administracyjnego albo spośród notariuszy Roty Rzymskiej ${ }^{159}$.

\subsubsection{Nawiązanie kontaktu $\mathrm{z}$ petentem i ewentualne uzupełnienie instrukcji sprawy}

Normy zobowiązują przewodniczącego kolegium do nawiązania pisemnego kontaktu z petentem i zapytania go, czy ma coś do

\footnotetext{
${ }^{156}$ Por. P. Amenta, La nuova normativa per lo svolgimento delle cause di dichiarazione di nullità dell'ordinazione: commento e primi rilievi, Folia Canonica 5 (2002) 176.

${ }^{157}$ Por. RS 2001, art. 24 \$ 1; Annuario Pontificio per l'anno 2020, Libreria Editrice Vaticana, Città del Vaticano 2020, 1195. Por. także: L. NAvarro, Nuovo regolamento per avviare e celebrare il procedimento amministrativo di nullità dell'ordinazione. Commento, w: Norme procedurali canoniche commentate, 254.

${ }^{158}$ Por. RS 2001, art. $24 \$ 2$. Por. także: L. NAvArRo, Nuovo regolamento per avviare e celebrare il procedimento amministrativo di nullità dell'ordinazione. Commento, w: Norme procedurali canoniche commentate, 254.

${ }^{159}$ Por. RS 2001, art. $24 \$ 3$. Por. także: L. NAVARro, Nuovo regolamento per avviare e celebrare il procedimento amministrativo di nullità dell'ordinazione. Commento, w: Norme procedurali canoniche commentate, 254.
} 
dodania, zwłaszcza czy pojawiły się nowe środki dowodowe (świadkowie, dokumenty) albo nowe argumenty, i do zachęcenia go, aby - o ile zechce - ustanowił sobie w Rzymie pełnomocnika, który by działał w jego imieniu w postępowaniu na szczeblu rzymskim w sprawie nieważności jego święceń. Pełnomocnik musi być kapłanem i biegłym w teologii i prawie kanonicznym ${ }^{160}$. Gdyby się okazało, że faktycznie pojawiły się nowe środki dowodowe albo nowe argumenty, przewodniczący powinien podjąć działania zmierzające do procesowego uzupełnienia instrukcji sprawy (przyjęcie dokumentu i/lub argumentów, zlecenie ordynariuszowi przesłuchania świadka) ${ }^{161}$.

\subsubsection{Votum obrońcy święceń}

Po ewentualnym uzupełnieniu instrukcji sprawy wszystkie akta dotychczasowego postępowania przewodniczący kolegium przekazuje obrońcy święceń, aby je uważnie zbadał i sporządził swoje votum. W tym celu przewodniczący kolegium powinien wyznaczyć obrońcy święceń odpowiednią ilość czasu ${ }^{162}$.

Jeśli obrońca święceń uzna, że sprawa jest już wystarczająco naświetlona przez zebrane środki dowodowe, wówczas przewodniczący kolegium przekazuje akta wszystkim członkom ustanowionego kolegium $^{163}$. Gdyby jednak opinia obrońcy święceń była odmienna, przewodniczący kolegium, rozważywszy uważnie stanowisko obrońcy węzła, postara się powiadomić kompetentnego ordynariusza o konieczności uzupełnienia instrukcji sprawy, stosownie do uwag obrońcy święceń, albo postanowi, że sprawa przechodzi do dalszego etapu postępowania ${ }^{164}$. Ewentualne uzupełnienie instrukcji sprawy odbędzie się zgodnie $\mathrm{z}$ uwagami obrońcy węzła i wytycznymi przewodniczącego kolegium oraz z zachowaniem przepisów dotyczących procesowego zbierania środków dowodowych, o których była mowa wyżej.

\footnotetext{
${ }^{160}$ Por. RS 2001, art. 25.

${ }^{161}$ Por. tamże, art. 25-26.

${ }^{162}$ Por. tamże, art. 26.

${ }^{163}$ Por. tamże, art. 27.

${ }^{164}$ Por. tamże.
} 


\subsubsection{Studium akt sprawy i podjęcie decyzji rozstrzygającej}

Przewodniczący kolegium, po ewentualnym uzupełnieniu instrukcji sprawy albo po podjęciu decyzji o dalszym kontynuowaniu sprawy pomimo zastrzeżeń ze strony obrońcy święceń, przekazuje akta sprawy wszystkim członkom kolegium, wyznaczając im jednocześnie odpowiedni czas - ale nie przekraczający jednego miesiąca - na studium sprawy i przygotowanie pisemnego votum. Powinien on również wyznaczyć dzień zebrania członków kolegium, w wyniku którego sprawa nieważności święceń zostanie rozstrzygnięta ${ }^{165}$. Zebranie odbywa się w obecności dziekana Roty Rzymskiej jako kierownika Urzędu Administracyjnego. W czasie zebrania najpierw komisarz ponens odczytuje swoje votum, a następnie pozostali komisarze przedstawiają własne opinie. Jeśli ci ostatni zgadzają się z votum ponensa, dochodzi natychmiast do podjęcia decyzji końcowej. W przypadku odmiennych opinii może się odbyć umiarkowana dyskusja w celu wyjaśnienia rozbieżności i przyjęcia - o ile to możliwe - jednomyślnego stanowiska. Każdy z komisarzy może swobodnie - w wyniku przeprowadzonej dyskusji - odstąpić od swego pierwotnego stanowiska i przychylić się do opinii innych członków kolegium ${ }^{166}$. Jeśli natomiast członkowie kolegium nie doszli do jednomyślnego stanowiska, dziekan Roty Rzymskiej jako kierownik Urzędu - po rozważeniu przeważającej opinii członków kolegium oraz ich uzasadnień prawnych i faktycznych - wydaje dekret, w którym powiadamia petenta i jego ordynariusza o decyzji końcowej. O podjętej decyzji należy powiadomić również obrońcę święcen ${ }^{167}$. Regulae servandae z 2001 roku nie wskazują, co wspomniany dekret powinien zawierać oprócz decyzji rozstrzygającej. Dotychczasowa praktyka - jak zauważają P. Amenta i L. Navarro - zamieszczała w dekrecie także uzasadnienie prawne

\footnotetext{
${ }^{165}$ Por. tamże, art. 28.

${ }^{166}$ Por. tamże, art. 29.

${ }^{167}$ Por. tamże, art. 30.
} 
i faktyczne podjętej decyzji ${ }^{168}$, co z kolei jest niezbędne, aby sporządzić i wnieść rekurs od przedmiotowego dekretu.

W tym momencie pojawia się jednak pytanie, kto podejmuje decyzję rozstrzygającą w sprawie o nieważność święceń, ponieważ sformułowania przepisów w Regulae servandae z 2001 roku nie są wystraczająco jasne. W odniesieniu do jednomyślnej opinii członków kolegium artykuł stwierdza: „statim devenitur ad finalem decisionem"169, natomiast w przypadku braku tej jednomyślności kolejny artykuł wyjaśnia: „[Decanus Tribunalis Rotae Romanae] (...) perspecto voto prevalenti Commissariorum eorumque rationibus in iure et in facto allatis, decisionem finalem Oratori euisque Ordinario communicet"170. Uważna analiza artt. 29 i 30 wydaje się wskazywać, że podmiotem podejmującym decyzję rozstrzygającą w każdym przypadku jest dziekan Trybunału Roty Rzymskiej jako kierownik Urzędu Administracyjnego - opierając się na pisemnych opiniach członków kolegium i na przedstawionych w nich uzasadnieniach prawnych i faktycznych, oraz na ich ewentualnej dyskusji - co z kolei stanowi podstawę do wyrobienia sobie przez niego pewności moralnej w rozpatrywanej sprawie i podjęcia decyzji rozstrzygającej.

\footnotetext{
${ }^{168}$ Por. P. Amenta, La nuova normativa per lo svolgimento delle cause di dichiarazione di nullità dell'ordinazione: commento e primi rilievi, Folia Canonica 5 (2002) 177; L. NAVAR Ro, Nuovo regolamento per avviare e celebrare il procedimento amministrativo di nullità dell'ordinazione. Commento, w: Norme procedurali canoniche commentate, 256-257.

${ }^{169}$ RS 2001, art. 29.

170 Tamże, art. 30.
} 
Takie stanowisko w tej kwestii zajmują P. Amenta ${ }^{171}$ i L. Navarro ${ }^{172}$. W każdym przypadku dekret rozstrzygający sprawę wydaje dziekan Roty Rzymskiej i on informuje o nim zainteresowanych, a przepisy nic nie wspominają ani o głosowaniu w kolegium komisarzy, a więc o decyzji kolegialnej, ani nie wymagają - do ważności orzeczenia jednomyślnej opinii członków kolegium.

\subsubsection{Zaskarżenie decyzji końcowej}

Podana do wiadomości zainteresowanych (petent, ordynariusz i obrońca święceń) decyzja może być przedmiotem zaskarżenia wniesionego przez obrońcę święceń i przez petenta w ciągu 10 dni od daty powiadomienia ich o wydanym dekrecie ${ }^{173}$. W przeciwnym wypadku rozstrzygnięcie sprawy o nieważność święceń stanie się prawomocne

171 “(...) il Presidente stabilisce il giorno del raduno collegiale (art. 28) nel quale ciascuno dei Commissari, radunati alla presenza del Prefetto o del Segretario del Dicastero, è invitato a leggere le proprie conclusioni in diritto ed in fatto (art. 29). E' prevista una moderata disceptatio in caso di discordanza di pareri: il fine è quello di raggiungere, per quanto possibile, l'unanimità, seppure dal tenore dell'art. 30 si comprenda che il voto dei Commissari è puramente consultivo e non vincoli in alcun modo i Superiori maggiori della Congregazione. Sono essi, infatti, a prendere la decisione finale e notificarla con un decreto della Congregazione (art. 31, §3). Il tenore dell'art. 30 sembra lasciare ai Superiori della Congregazione un'ampia discrezionalità di giudizio ed è formulato di proposito in maniera «aperta», vale a dire, lasciando intravedere la possibilità di una soluzione negativa ma anche di una soluzione affermativa pro nullitate" (P. AMENTA, La nuova normativa per lo svolgimento delle cause di dichiarazione di nullità dell'ordinazione: commento e primi rilievi, Folia Canonica 5 (2002) 176).

${ }^{172}$ „Tuttavia, la decisione finale non sembra sia del collegio, ma del Decano della Rota Romana, mediante decreto, anche nei casi in cui vi fosse un parere unanime (art. 30)" (L. NAVARRo, Nuovo regolamento per avviare e celebrare il procedimento amministrativo di nullità dell'ordinazione. Commento, w: Norme procedurali canoniche commentate, 256). "La decisión sobre el caso la toma el decano de la Rota, mediante decreto" (L. NAVArRo, Nulidad de la sagrada ordenación [causas de], w: Dicionario General de Derecho Canónico, V, 600.

${ }^{173}$ Por. RS 2001, art. $31 \$ 1$. 
i należy je wykonać, o czym trzeba powiadomić kompetentnego ordynariusza dekretem dziekana Roty Rzymskiej ${ }^{174}$.

Duchowny, który wnioskował o stwierdzenie nieważności przyjętych święceń, swoje zaskarżenie podjętej przez dziekana Roty Rzymskiej decyzji wnosi za pośrednictwem swojego ordynariusza albo pełnomocnika. Zaskarżenie należy zgłosić do tego samego Urzędu Administracyjnego przy Rocie Rzymskiej, natomiast w ciągu jednego miesiąca należy przedstawić uzasadnienie prawne i faktyczne wniesionego rekursu ${ }^{175}$. Bezskuteczny upływ tego terminu spowoduje, że orzeczenie stanie się prawomocne.

W Urzędzie Administracyjnym sprawą zajmie się kolejny turnus - wyznaczony przez dziekana Roty Rzymskiej - złożony z trzech lub pięciu komisarzy, z których jednemu należy powierzyć funkcję przewodniczącego kolegium i ponensa sprawy ${ }^{176}$. Przewodniczący kolegium powinien wysłuchać, w zależności od przypadku, petenta albo obrońcę święceń i zapytać, czy chce przedstawić krótkie uwagi na temat tego, co przedstawił petent ${ }^{177}$. Po wyznaczeniu przez przewodniczącego daty zebrania kolegium, w obecności dziekana Roty Rzymskiej, postępowanie odbywa się zgodnie z przepisami przedstawionymi wyżej (artt. 28-29) i w konsekwencji dochodzi się do podjęcia decyzji przez dziekana ${ }^{178}$, który następnie umotywowanym prawnie i faktycznie dekretem powiadamia petenta i jego ordynariusza o rozstrzygnięciu rekursu ${ }^{179}$. Regulae servandae z 2001 roku przewidują, że przeciwko dekretowi rozstrzygającemu wspomniany rekurs istnieje jeszcze możliwość wniesienia skargi sporno-administracyjnej do Naj-

\footnotetext{
${ }^{174}$ Por. tamże. W wyniku orzeczenia nieważności święceń duchowny: traci wszystkie uprawnień właściwe stanowi duchownemu; nie podlega żadnym obowiązkom stanu duchownego, włącznie z obowiązkiem celibatu; ma zakaz wykonywania władzy święceń; zostaje pozbawiony wszystkich urzędów, zadań i wszelkiej władzy delegowanej (por. KPK 1983. kann. 291-292).

${ }^{175}$ Por. tamże.

${ }^{176}$ Por. tamże, artt. $31 \S 2$ i $24 \$ 1$.

${ }^{177}$ Por. tamże, art. $31 \S 2$.

${ }^{178}$ Por. tamże.

${ }^{179}$ Por. tamże, art. $31 \S 3$.
} 
wyższego Trybunału Stolicy Apostolskiej w terminie sześćdziesięciu dni, zgodnie z art. $123 \$ 1$ konstytucji apostolskiej Pastor bonus i art. $34 \$ 1$ Lex propria Supremi Tribunalis Signaturae Apostolicae z 21 czerwca 2008 roku. Trzeba jednak pamiętać, że tego rodzaju skarga jest ograniczona wyłącznie do zweryfikowania legalności wydanej decyzji, a więc czy zaskarżony konkretny akt administracyjny naruszył przepis prawa materialnego albo formalnego, a nie dotyczy zweryfikowania rozstrzygnięcia merytorycznego ${ }^{180}$.

Jeśli Sygnatura Apostolska uzna, że nie został naruszony żaden przepis prawa materialnego albo formalnego, wówczas petentowi pozostaje możliwość złożenia prośby do Biskupa Rzymu o udzielnie mu dyspensy od wszystkich obowiązków wynikających z przyjętych święceń, włącznie z obowiązkiem zachowania celibatu ${ }^{181}$.

\section{Zakończenie}

W kwestii rozpatrywania i orzekania spraw o nieważność święceń aktualny Kodeks Prawa Kanonicznego uregulował jedynie postępowanie sądowe, natomiast nie wskazał przepisów regulujących postępowanie administracyjne, które również może być zastosowane w tego rodzaju sprawach. W związku z tym Kongregacja Kultu Bożego i Dyscypliny Sakramentów, dostosowując przepisy wykonawcze do postanowień kodeksowych, opracowała i wydała stosowne normy, aby udostępnić ordynariuszom odpowiednie wytyczne, dostosowane do obecnego Kodeksu, i określić procedurę stosowaną w Stolicy Apostolskiej.

Przedmiotowe postępowanie administracyjne obejmuje dwa etapy, mianowicie instrukcję sprawy, którą przeprowadza ordynariusz upoważniony przez kierownika Urzędu Administracyjnego przy Rocie

\footnotetext{
${ }^{180}(\ldots)$ num actus impugnatus legem aliquam in decernendo vel in procedendo violaverit” (PB, art. $123 \$ 1$ ). Por. także: Benedictus XVI, Lex propria Supremi Tribunalis Signaturae Apostolicae, 21.06.2008, art. 34 \$1, w: EV, XXV, 634.

${ }^{181}$ KPK 1983, kan. 291; Segreteria Di Stato, Lettera al Prefetto della Congregazione per il Clero, 21.06.2005, N.907, w: Archivio della Congregazione per il Clero; Congregazione per il Culto Divino e la Disciplina dei Sacramenti. Profilo, w: http:// www.cultodivino.va/content/cultodivino/it/dicastero/profilo.html [20.08.2020].
} 
Rzymskiej, którym jest dziekan Roty Rzymskiej, oraz studium i rozstrzygnięcie sprawy, należące do kompetencji tegoż Urzędu.

Normy regulujące badane postępowanie uwzględniają wszystkie istotne elementy zmierzające do wyrobienia sobie pewności moralnej przez komisarzy i przez dziekana Roty Rzymskiej w celu rozpoznania i rozstrzygnięcia sprawy, i jednocześnie gwarantują ochronę praw duchownego, który złożył skargę o stwierdzenie nieważności swoich święceń, co uwidacznia się w różnych momentach tegoż postępowania: ustanowienie sobie pełnomocnika przez duchownego; prawo duchownego do poznania tożsamości świadków z urzędu i do złożenia wniosku o ich wyłączenie; dodatkowe uprawnienia obrońcy święceń; rekursy od pierwszego i drugiego dekretu dziekana Roty Rzymskiej; odrębne kolegium rozpatrujące rekurs przeciwko pierwszemu dekretowi rozstrzygającemu sprawę i możliwość wniesienia kolejnego rekursu do Najwyższego Trybunału Sygnatury Apostolskiej.

Sprawny przebieg instrukcji sprawy możliwy jest dzięki przewidzianym uprawnieniom ordynariusza i instruktora w zakresie wyznaczania urzędników i pomocników oraz odstępowania od procedury, jeśli domaga się tego słuszna przyczyna, a także dzięki zobowiązaniu ordynariusza do uważnego czuwania nad przebiegiem instrukcji i nad wiernym stosowaniem przewidzianych norm.

\section{Declaration of nullity of sacred ordination in administrative proceedings}

The administrative proceeding in the matter of the declaration of the nullity of sacred ordination is currently regulated by Regulae servandae instruction of 16 October 2001 issued by the Congregation for Divine Worship and the Discipline of the Sacraments, which since 1 October 2011 has been applied in accordance with the changes introduced by Pope Benedict XV in the motu proprio Querit semper of 30 August 2011. This instruction replaced the previous Regulae servandae issued on 9 June 1931 by the Congregation for the Discipline of the Sacraments. 
The whole procedure consists of two stages: the case instruction, conducted by an ordinary authorized by the head of the Administrative Office of the Roman Rota (here the dean of the Roman Rota) and the legal decision of the case (in the competences of the Office).

The studied regulations, adjusted to the Canon Law Code of 1983, guarantee protection of the rights of the priest who lodged a claim concerning declaration the nullity of sacred ordination and lead to forming moral certainty by the commissioners and the dean of the Roman Rota while dealing with the case.

Efficient case instruction is possible due to the ordinary and instructor eligibility regarding designation of clerks and assistants as well as dispensing with the procedure when it is demanded by a rightful cause. Another factor is the ordinary's liability to watch over the observance of the law and application of the prescribed norms.

SŁowA KLUCzowe: stwierdzenie nieważności święceń; libellus; ordynariusz; instruktor sprawy; obrońca święceń; instrukcja sprawy; wnioskodawca; dowody; votum instruktora; votum ordynariusza; Urząd Administracyjny Roty Rzymskiej; kolegium komisarzy; odwołanie się od dekretu dziekana Roty Rzymskiej

KEYwORDs: declaration of nullity of sacred ordination; libellus; ordinary; case instructor; ordination defender; case instruction; petitioner; proofs; instructor's votum; ordinary's votum; Administrative Office of the Roman Rota; college of commissioners; recourse against a decree of the dean of the Roman Rota

\section{NotA O AUTORZE}

O. Prof. Dr hab. Wieslaw Kiwior OCD - kapłan Zakonu Karmelitów Bosych, profesor Wydziału Prawa Kanonicznego Uniwersytetu Kardynała Stefana Wyszyńskiego w Warszawie. W latach 2012-2016 prodziekan Wydziału; kierownik Katedry Kanonicznego Prawa Karnego, administracyjnego i Procesowego; kierownik Zakładu kanonicznego Prawa Procesowego. Autor licznych publikacji naukowych. 